\title{
Sitem Kendali Dan Monitoring Boost Converter Berbasis GUI (Graphical User Interface) Matlab Menggunakan Arduino
}

\author{
Aswaldi Alfaris ${ }^{1}$, Muldi Yuhendri ${ }^{2}$ \\ ${ }^{1,2}$ Universitas Negeri Padang \\ Jl. Prof Dr. Hamka Air Tawar, Padang, Indonesia \\ aswaldialfaris1@gmail.com ${ }^{1}$. muldiyuhendri@gmail.com ${ }^{2}$
}

\begin{abstract}
This article discusses the design of a DC-DC converter type Boost Converter (voltage booster). This circuit uses a GUI (Graphical User Interface) as monitoring. To increase the Boost Converter voltage, it is done by adjusting the PWM (Pulse Width Modulation) using a pot. Arduino as a controller to receive the response from sensor readings. To adjust the size of the $P W M$, a switching component is used in the form of a mosfet. Gate drives are used as signal amplifiers and safety between the control circuit and the main circuit. The input voltage of this converter is 12VDC with a variable output voltage of 12VDC-24VDC with Efficiency ranging from $80 \%$ to $99 \%$. The greatest efficiency of the load used is at $23.85 \mathrm{~W} 12 \Omega$ load with an output voltage of $15 \mathrm{~V}$, which is an efficiency of $99 \%$. In this circuit the GUI has been successfully added to display some data from the voltage sensor (Volt) and current sensor (Ampere) readings. The results of the sensor readings in the form of values and graphs are displayed on a PC using Matlab's Graphical User Interface (GUI) software.
\end{abstract}

Keywords-Boost Converter, Arduino, PWM, GUI Matlab.

\begin{abstract}
Abstrak-Artikel ini membahas tentang perancangan sebuah rangkaian converter DC-DC tipe Boost Converter(Penaik tegangan). Rangkaian ini menggunakan GUI (Graphical User Interface) sebagai monitoring. Untuk menaikkan tegangan Boost Converter dilakukan dengan mengatur PWM (Pulsa Width Modulation) menggunakan potensio. Arduino sebagai kontroler penerima respon dari pembacaan sensor. Untuk mengatur besar kecilnya PWM digunakan komponen switching berupa mosfet. Gate drive digunakan sebagai penguat sinyal dan pengaman antara rangkain kontrol dan rangkaian utama. Tegangan masukkan konverter ini adalah 12VDC dengan tegangan keluaran variabel 12VDC-24VDC dengan Efisiensi berkisar antara $80 \%$ hingga $99 \%$. Efisiensi terbesar dari beban yang digunakan adalah pada beban $23,85 \mathrm{~W} 12 \Omega$ dengan tegangan keluaran 15V yaitu efisiesi sebesar 99\%. Pada rangkaian ini GUI berhasil ditambahkan untuk menampilkan beberapa data dari pembacaan sensor tegangan(Volt) dan sensor arus(Ampere). Hasil dari pembacaan sensor berupa nilai dan grafik ditampilkan pada PC menggunakan software Graphical User Interface (GUI) Matlab.
\end{abstract}

Kata kunci-Boost Converter, Arduino, PWM, GUI Matlab.

\section{Pendahuluan}

DC-DC Konverter merupakan suatu alat yang penyedia daya tegangan searah (DC) yang dihasilkan melalui konversi tegangan DC masukan kebentuk tegangan DC keluaran yang lebih rendah atau tinggi. Penerapan DC-DC konverter telah memungkinkan suatu perangkat elektronika dapat berfungsi dengan sumber energi yang berukuran kecil, dimana tegangan keluarannya dapat diubah sesuai kebutuhan. Hingga saat ini berbagai konfigurasi dc-dc converter telah banyak dikembangkan diantaranya adalah jenis dc-dc converter yang menggunakan tipe boost converter[1].

Kebutuhan akan tegangan keluaran searah yang bervariasi dapar terpenuhi dengan adanya converter boost (regulator DC non-isolated). Boost Converter adalah jenis konverter daya DC ke DC dimana tegangan keluaran sama atau lebih tinggi dari tegangan masukkan. Tegangan keluaran konverter ini dinaikkan dengan menyesuaikan lebar pulsa PWM(pengaturan duty cycle). [2] [3][4]
Boost Converter (Step-Up Converter) merupakan DC to $D C$ converter yang menghasilkan tegangan output yang jauh lebih besar dari tegangan inputnya. Boost Converter ini termasuk ke dalam rangkaian Switched-Mode Power Supply (SMPS) yang setidaknya terdapat dua switch semikonduktor seperti dioda dan transistor serta setidaknya satu komponen penyimpan energi seperti kapasitor atau induktor.[5]

Perancangan sebuah rangkaian konverter DC-DC tipe Boost (penaik tegangan) dapat dilakukan dengan GUI monitoring. Kenaikan tegangan keluaran dari konverter dilakukan dengan mengatur lebar pulsa (PWM). Pengubahan besar kecilnya PWM dilakukan dengan meggunakan komponen switching berupa MOSFET, serta penggunaan gate drive yang berfungsi sebagai penguatan sinyal dan pengaman antara rangkaian kontrol dan rangkaian utamanya. GUI berhasil ditambahkan untuk menampilkan beberapa variabel seperti tegangan (Volt), arus (Ampere), serta grafik tegangan masukan dan keluaran dari konverter boost.[6] 
Berdasarkan penelitian diatas penulis berinovasi membuat perancangan Boost Converter yang bervariabel 12V-24V DC dengan menambah monitoring menggunakan GUI (graphical user interface) Matlab untuk menampilakan Grafik tegangan dan arus yang dihasilkan.

\section{Boost Converter}

Boost Converter merupakan salah satu jenis topologi dasar pensaklaran. Topologi boost converter bisa menghasilkan tegangan keluaran yang lebih tinggi dibanding tegangan masukannya.

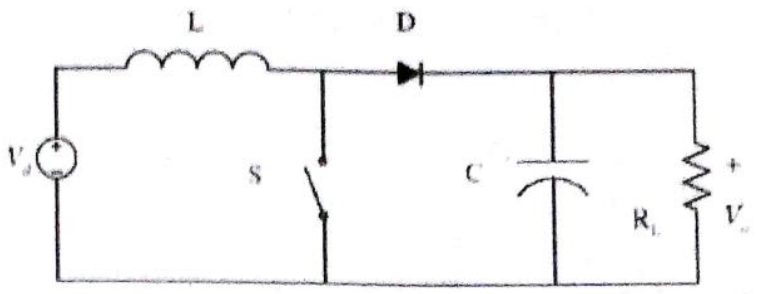

Gambar 1. Rangkaian Boost Converter.

[7]

Boost converter bekerja pada dua mode. Mode pertama adalah saat MOSFET on, tegangan induktor sama dengan tegangan masukan. Dioda dalam kondisi prategangan mundur. Induktor akan mulai menyimpan energi dalam bentuk energi magnetik. Energi yang tersimpan pada kapasitor digunakan untuk mensuplai beban.[8]

\section{Mikrokontroller ATMega 2560}

Arduino adalah perangkat mikrocontroler yang bersifat open source, yang menggunakan IC mikrokontroler ATMega sebagai komponen utamanya. Meskipun memakai IC dari AVR Atmel, namun pemograman arduino menggunakan bahasa pemograman tersendiri. Arduino juga berperan penting dalam pengendalian berbagai macam perangkat dan rangkaian elektronik, maupun untuk pengendalian berbagai macam motor. Arduino memiliki berbagai macam seri, salah satunya adalah Arduino Mega 2560. Pda gambar 3 dapat dilihat bentuk fisik Arduino Mega 2560.[9]

DF ROBOT ARDUINO Mega USB Microcontroller ( ATMEGA 2560) adalah suatu mikrokontroler pada ATMEGA 2560 yang mempunyai 54 input/ output digital yang mana 16 pin digunakan sebagai PWM keluaran, 16 masukan analog, dan di dalamnya terdapat16 MHZ osilator kristal, USB koneksi, power, ICSP, dan tombol reset.[10]

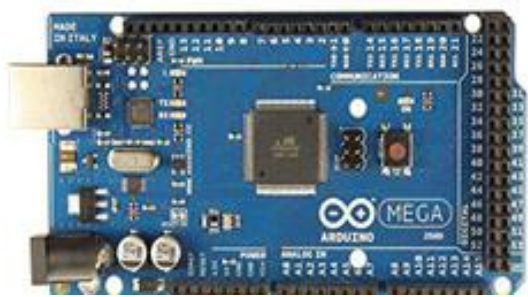

Gambar 2. Board Mikrokontroler Arduino Mega 2560

\section{Pulse Width Modulation (PWM)}

metode pengendalian DC-DCconverterpada dasarnya dapat dilakukan dengan cara pengendalian lebar pulsa penyalaan atau mode operasi dengan frekuensi tetap. Metode PWM ini dilakukan dengan memvariasikan lebar pulsa $\left(\mathrm{T}_{O N}\right)$ dari gelombang keluaran dengan frekuensi chopping tetap. Berikut bentuk gelombang tegangan keluaran untuk waktu konduksi yang berbeda.

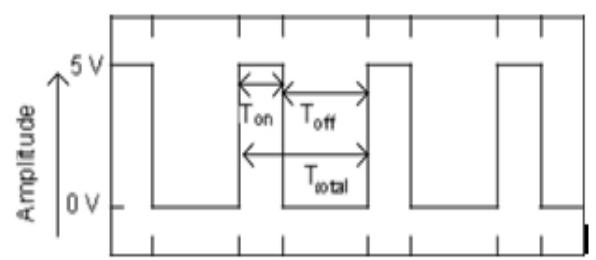

Gambar 3. Bentuk gelombang PWM

\section{Sensor Arus ACS712}

Sensor ACS712 Low Current Sensor Breakout ini yang merupakan produk dari Allegro mempunyai tingkat pengukuran arus dari rentang mili hingga 5 ampere, dan telah dilengkapi dengan penguat sehingga memudahkan pengguna untuk mengukur arus.[11]

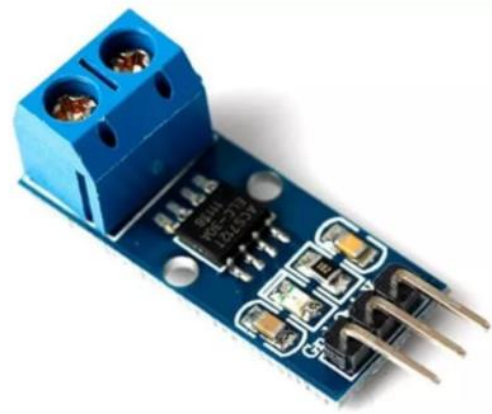

Gambar 4. Sensor ACS712

\section{Mosfet}

komponen dengan kecepatan switching yang sangat tinggi bahkan kecepatan switching memiliki orde nanodetik dan dikendalikan oleh tegangan serta memerlukan arus masukan yang kecil merupakan beberapa ciri-ciri dari MOSFET.

Rangkaian TLP250 digunakan untuk mengisolasi dan menguatkan sinyal PWM tegangan 5 volt yang dibangkitkan mikrokontroller menjadi level tegangan yang lebih tinggi dengan sistem ground terpisah dan 
cukup untuk memicu MOSFET yang membutuhkan tegangan VGS $\pm 20 \mathrm{~V}$.[12]

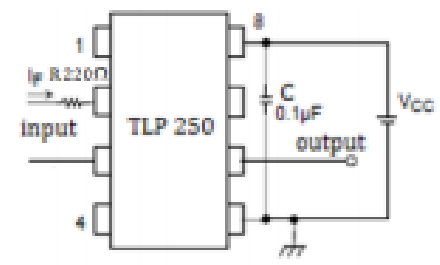

Gambar 4. Rangkaian TLP250

\section{GUI Matlab}

Matlab memiliki fasilitas pengembangan berupa GUI (Graphic User Interface). GUI Designer mengandung menu, tombol, teks, grafik, dan lain-lain dimana pengguna dapat mengubahnya secara interaktif dengan menggunakan mouse dan keyboard.[13]

GUIDE Matlab mempunyai kelebihan tersendiri dibandingkan dengan bahasa pemrogram lainnya, diantaranya:

a. GUIDE Matlab banyak digunakan dan cocok untuk aplikasi-aplikasi berorientasi sains, sehingga banyak peneliti dan mahasiswa menggunakan GUIDE Matlab untuk menyelesaikan riset atau tugas akhirnya.

b. GUIDE Matlab mempunyai fungsi built-in yang siap digunakan dan pemakai tidak perlu repot membuatnya sendiri.

c. Ukuran file, baik FIG-file maupun M-file, yang dihasilkan relatif kecil.

d. Kemampuan grafisnya cukup andal dan tidak kalah dibandingkan dengan bahasa pemrograman lainnya.

\section{METODE}

Pada bab ini akan membahas tentang perancangan hardware dan software yang terdiri dari blok diagram, perancangan mekanik dan flowchart.

\section{Blok Diagram}

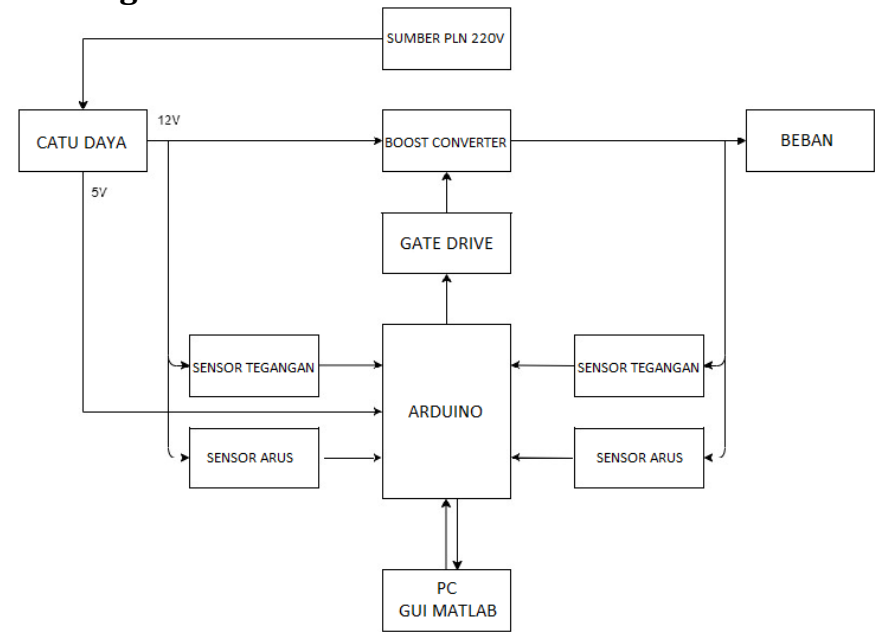

Gambar 5. Blok Diagram Keseluruhan
Berdasarkan blok diagram keseluruhan sistem di atas, fungsi dari masing-masing blok diagram sebagai berikut:

1. Catu Daya

Catu Daya berfungsi untuk ,menyearahkan tegangan 220 V AC menjadi 12 VDC \& 5 VDC.

2. Boost Converter

Boost Converter merupakan bagian yang berfungsi untuk menaikkan tegangan $12 \mathrm{~V}$ ke nilai tegangan yang diinginkan dengan range sampai $24 \mathrm{~V}$.

3. Rangkaian Gate Drive

Rangkaian Gate Drive merupakan rangkaian yang digunakan untuk mengaktifkan dan menswitching gate mosfet.

4. Mikrokontroler

Arduino Mega2560 adalah mikrokontroler yang digunakan dimana berfungsi sebagai prosesor kerja alat-alat yang akan dibuat. Arduino akan menghasilkan pulsa PWM untuk modulasi mosfet.

5. Sensor Tegangan

Sensor Tegangan berfungsi untuk mengetahui tegangan masukkan dan keluaran dari Boost Converter

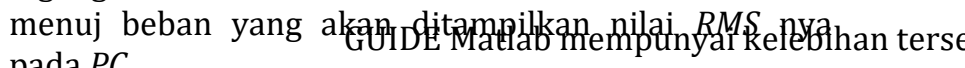
pada $P C$.

6. Sensor Arus

Sensor Arus ACS712 berfungsi sebagai pendeteksi besar arus masukan dan keluaran Boost Converter.

7. Beban

Beban yang digunakan adalah beban resistor $27 \mathrm{ohm}$ dan $47 \mathrm{ohm}$.

8. Personal Computer

Personal computer berfungsi sebagai unit penampil data yang dapat deprogram melalui Arduino yang menggunakan GUI (Graphical User Interface) Matlab sebagai Interfacing nya.

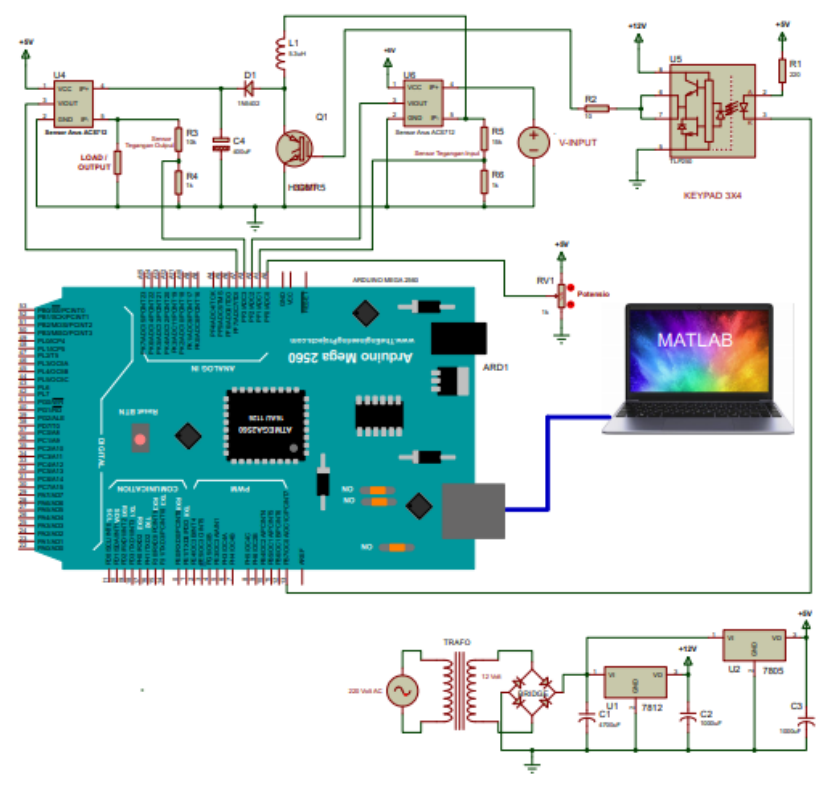

Gambar 6. Rangkaian Elektronika Keseluruhan 


\section{Perancangan Mekanik(hardware)}

Perancangan mekanik hardware merupakan hal yang sangat penting dalam pembuatan tugas akhir ini, karena merupakan suatu tahapan atau proses dalam pembuatan suatu perangkat keras. Perancangan ini bertujuan agar sistem dapat diuji secara nyata apakah tugas akhir ini dapat bekerja dengan baik atau tidak. Rancangan hardware dari tugas akhir ini dapat dilihat seperti dibawah ini.

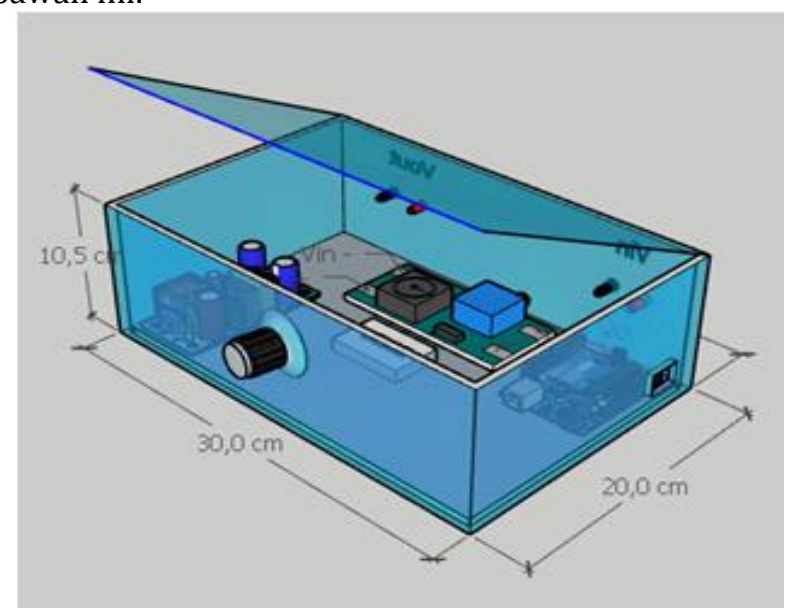

Gambar 7. Rancangan Hardware

\section{Perancangan Perangkat Lunak(Sofeware)}

Perancangan perangkat lunak pada proses pembuatan alat ini meliputi pemrograman pengendali pada mikrokontroller dari mengolah data masukan dari sensor, menjadi suatu aksi yang berupa logika, keluaran dimana mikrokontroller yang digunakan adalah Arduino ATMega 2560. Dalam perancangan ini digunakan GUI Matlab sebagai monitoring untuk menampilkan angka dan grafik.

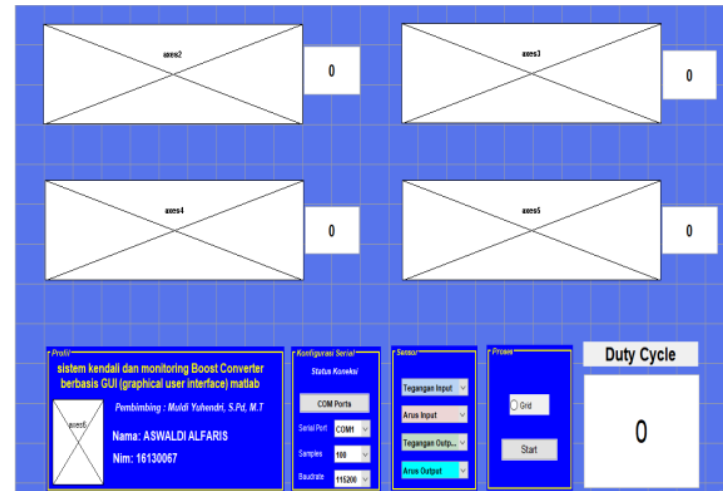

Gambar 8. Tampilan GUI Matlab sebelum di RUN

\section{Flowchart}

Prinsip kerja alat ini dijelaskan melalui suatu gambar atau bagan yang menunjukkan langkah atau urutan suatu program. Flowchart untuk sistem kendali dan monitoring Boost Converter berbasis GUI Matlab ditujukkan pada gambar 4.

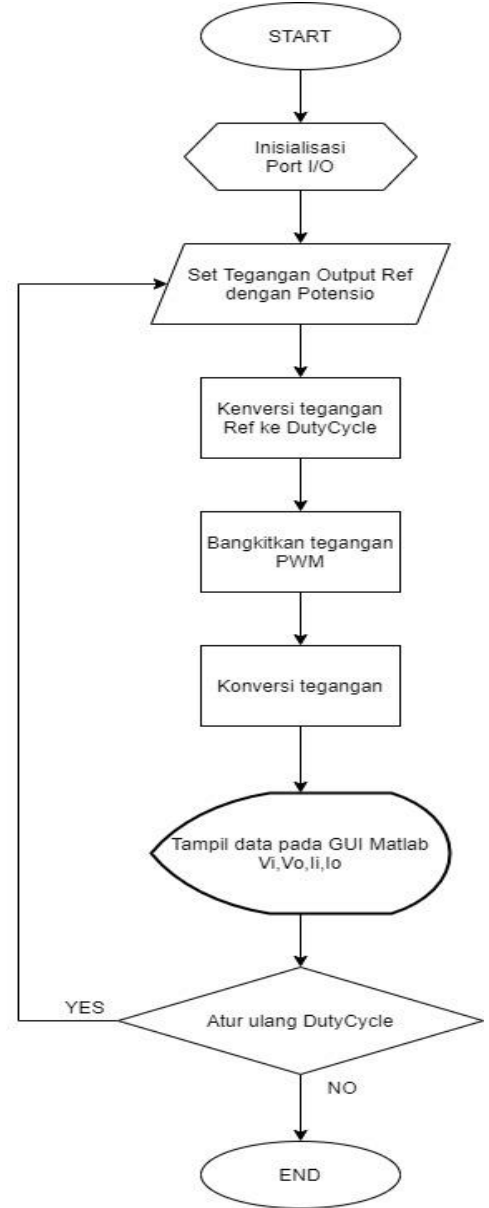

Gambar 9. Flowchart Sitem Boost Converter

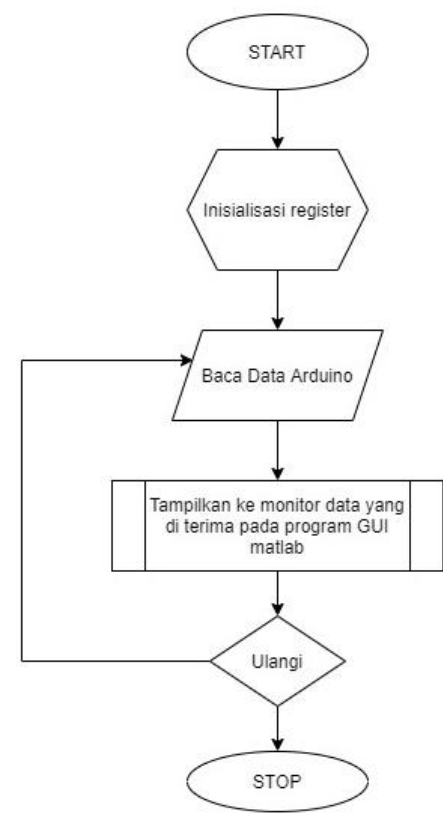

Gambar 10. Flowchart Sistem GUI Matlab 
Pada dasarnya prinsip kerja pada alat ini adalah pengaturan tegangan terhadap boost converter yang menaikkan tegangan catu daya $12 \mathrm{~V} \mathrm{DC}$ menjadi tegangan keluaran yang bervariabel dengan maksimum tegangan sampai 24 V. Sumber PLN 220V ke catu daya untuk menyearahkan tegangan menjadi 5VDC dan 12VDC. Untuk tegangan 5VDC digunakan sebagai penyuplai tegangan untuk Arduino ATMega2560, kontrol dengan potensio, dan rangkaian Gate Drive. Untuk tegangan 12 VDC digunakan sebagai penyuplai tegangan untuk rangkaian boost Converter.

Rangkaian boost konverter ini menggunakan Mosfet sebagai komponen switching nya. Untuk mengaktifkan gate Mosfet digunakan mikrokontroler Arduino ATMega2560 sebagai kontrol pengaturana besar kecilnya nilai duty cycle yang akan di inputkan ke gate Mosfet rangkaian boost converter sekaligus sebagai pengatur keluaran dari boost konverter tersebut. Pada rangkaian ini kontrol pengaturan besar kecilnya duty cycle menggunakan potensiometer.

Sehingga dapat menaikkan tegangan menjadi tegangan yang diinginkan menggunakan potensio. Besarnya tegangan output boost converter yang dideteksi oleh sensor tegangan akan dikonversi oleh Mikrokontroler sehingga nilai tegangan output dan nilai duty cycle yang diberikan dapat dilihat pada tampilan PC dengan software GUI MATLAB

\section{HASIL DAN PEMBAHASAN}

Pengujian alat dilakukan untuk mengetahui apakah alat yang dibuat bekerja dengan baik atau tidak. Adapun beberapa pengujian yang penulis lakukansebagai berikut.

1. Pengujian Catu Daya

Pengujian dilakukan untuk tegangan masukan power supply dan tegangan keluaran 5VDC dan 12VDC dari catu daya tersebut. Berikut hasilnya

Tabel 1. Hasil Pengujian Catu Daya

\begin{tabular}{|c|c|c|}
\hline No & Parameter Yang Diukur & $\begin{array}{c}\text { Hasil } \\
\text { Pengukuran }\end{array}$ \\
\hline 1 & Tegangan Sumber (PLN) & 220 VAC \\
\hline 2 & $\begin{array}{c}\text { Tegangan Keluaran Catu } \\
\text { Daya 12 V }\end{array}$ & 11,72 VDC \\
\hline 3 & $\begin{array}{c}\text { Tegangan keluaran Catu } \\
\text { Daya 5 V }\end{array}$ & 4,96 VDC \\
\hline
\end{tabular}

\section{Gate Drive}

Pengujian rangkaian gate drive ini dilakukan dengan cara menghubungkan rangkaian gate drive dengan catu daya 5VDC, dan menghubungkan sinyal keluaran PWM yang dihasilkan oleh mikrokontroler ATMega2560 ke bagian masukkan rangkaian gate drive dan melihat gelombang keluaran yang dihasilkan gate drive menggunakan oscilloscope.

Probe oscilloscope dihubungkan ke kaki 6 TLP 250 dan Ground Clip Oscilloscope dihubungkan ke kaki 5 TLP250. Berikut adalah data hasil pengujian PWM dari mikrokontroler dan bentuk gelombang Gate driver. Bentuk sinyal PWM keluaran dari gate drive dengan duty cycle ditunjukkan pada table 2 .

table 2. Pengamatan Gate Driver

\begin{tabular}{|l|c|c|c|}
\hline No & $\begin{array}{c}\text { Duty } \\
\text { Cycle } \\
(\%)\end{array}$ & $\begin{array}{c}\text { Tegangan } \\
\text { Output }\end{array}$ & $\begin{array}{c}\text { Gambar } \\
\text { Gelombang } \\
\text { Oscilloscope }\end{array}$ \\
\hline 1. & $21 \%$ & 15 & \\
\hline 2. & $32 \%$ & 18 & \\
\hline 3. & $50 \%$ & 24 & \\
\hline
\end{tabular}

Berdasarkan pengujian yang telah dilakukan, semakin tinggi duty cycle maka nilai tegangan keluaran gate driver semakin besar. Perubahan nilai duty cycle juga akan mempengaruhi bentuk gelombang keluaran pada oscilloscope.

\section{Pengujian Boost Converter}

Pengujian pada rangkaian konverter boost dilakukan dengan memberikan sumber tegangan DC 12 $\mathrm{V}$ dan diberikan beban load resistor. Besar frekuensi switching yang digunakan adalah 20KHz. Dari data hasil pengukuran didapat besar tegangan dan arus maukan serta tegangan dan arus keluaran melalui PC.

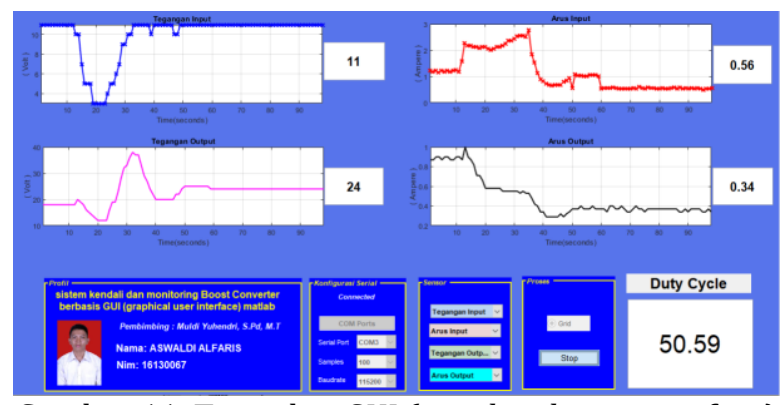

Gambar 11. Tampilan GUI (graphical user interface) 
Tabel 3. Hasil Pengujian Boost Converter $50 \Omega$

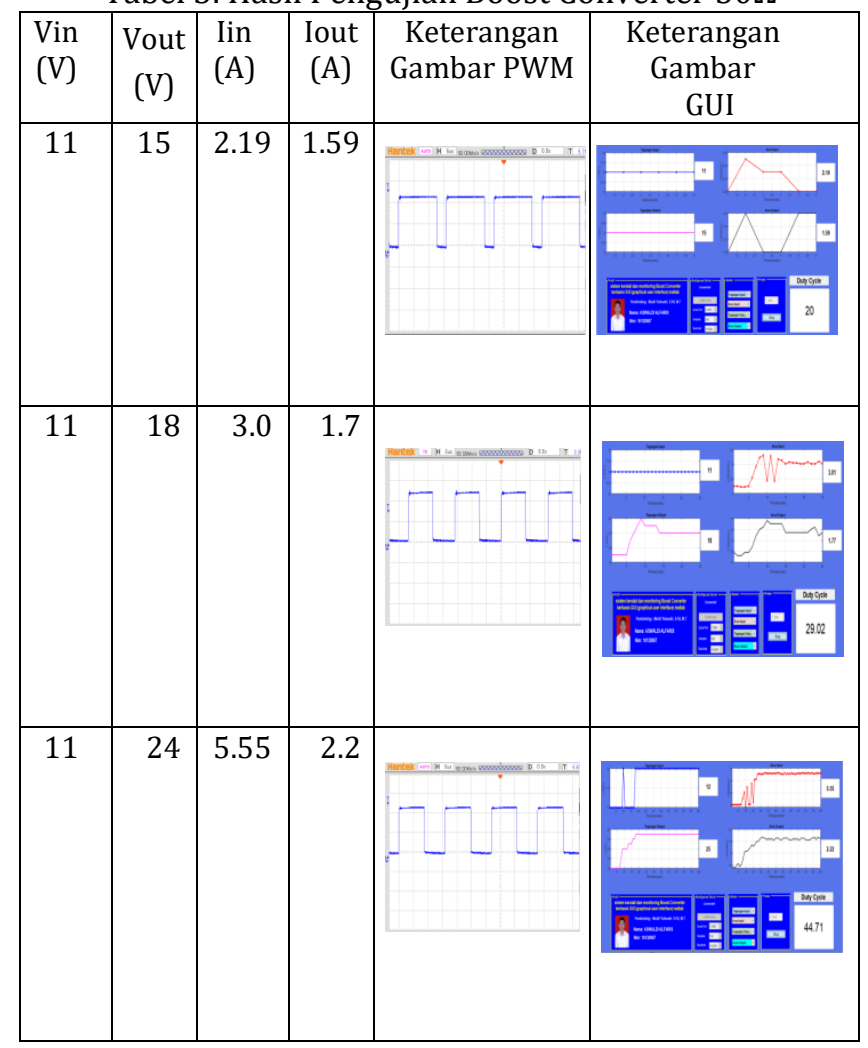

Tabel 4. Hasil Pengujian Boost Converter $100 \Omega$

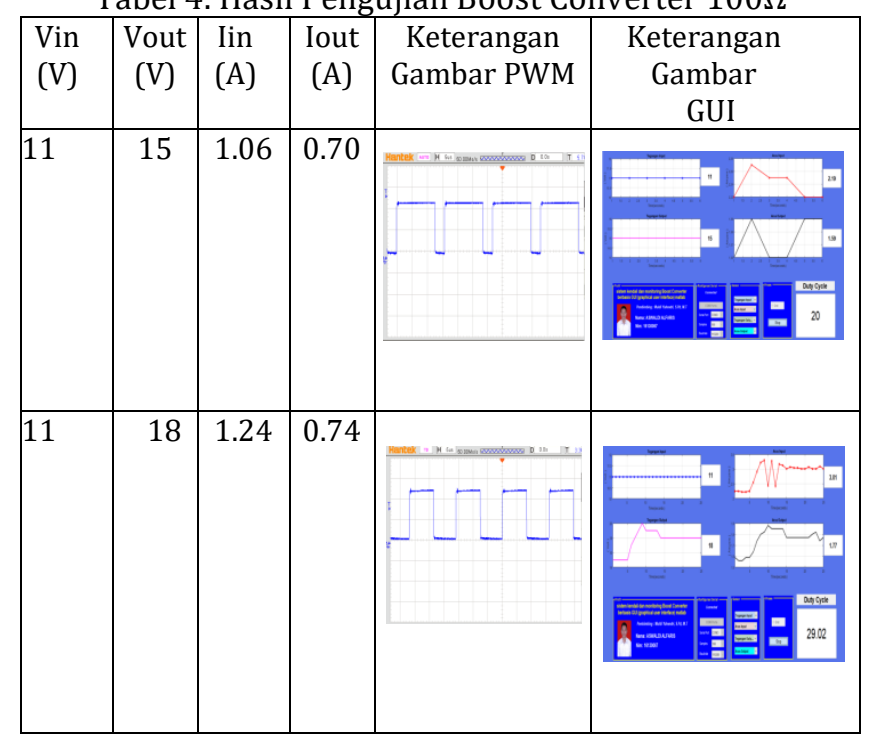

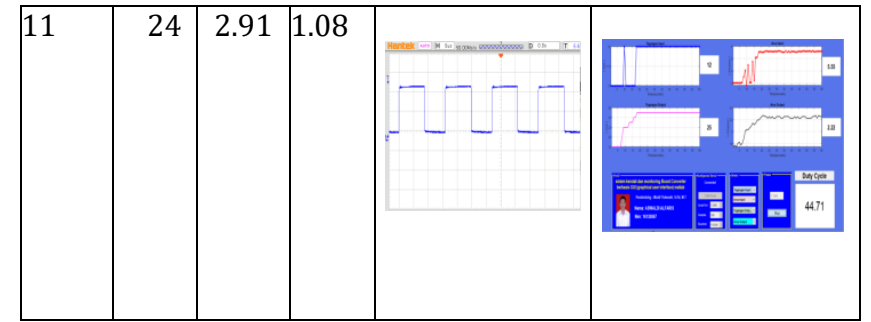

Dari pengukuran yang telah dilakukan dapat dilihat data pengujian alat pada Tabel 3 berikut:

Table 5. Data pengujian alat

\begin{tabular}{|c|c|c|c|c|c|c|c|}
\hline$\Omega$ & $\begin{array}{l}\text { Vin } \\
\text { (V) }\end{array}$ & $\begin{array}{l}\text { Vout } \\
\text { (V) }\end{array}$ & $\begin{array}{l}\text { Ii } \\
\text { n } \\
\text { (A) }\end{array}$ & $\begin{array}{l}\text { Iout } \\
\text { (A) }\end{array}$ & $\begin{array}{l}\text { Pin } \\
= \\
\text { Vin. } \\
\text { In } \\
(W)\end{array}$ & $\begin{array}{l}\text { Pout } \\
= \\
\text { Vout. } \\
\text { Iout } \\
\text { (W) }\end{array}$ & $\begin{array}{c}\eta \\
= \\
\frac{P_{\text {out }}}{P_{\text {in }}} \times 100\end{array}$ \\
\hline \multirow{3}{*}{12} & 11 & 15 & 2.1 & 1.5 & 24 & 23 & $99 \%$ \\
\hline & 11 & 18 & 3 & 1.7 & 36 & 31.8 & $96.2 \%$ \\
\hline & 11 & 24 & 5.5 & 2.2 & 64 & 53 & $83.1 \%$ \\
\hline \multirow{4}{*}{24} & 11 & 15 & 1 & 0.7 & 11 & 11.1 & $90 \%$ \\
\hline & & & & & & & \\
\hline & 11 & 18 & 1.2 & 0.7 & 13 & 16.2 & $81.3 \%$ \\
\hline & 11 & 24 & 2.9 & 1.0 & 31 & 25.9 & $81.2 \%$ \\
\hline
\end{tabular}

IoUT diatas dapat dilihat bahwa setiap perubahan beban yang semakin besar maka arus keluaran boost converter juga semakin kecil. Bertambahnya duty cycle karena beban yang semakin besar juga dapat mempengaruhi tegangan keluaran boostconverter dan berakibat pada efisiensi alat

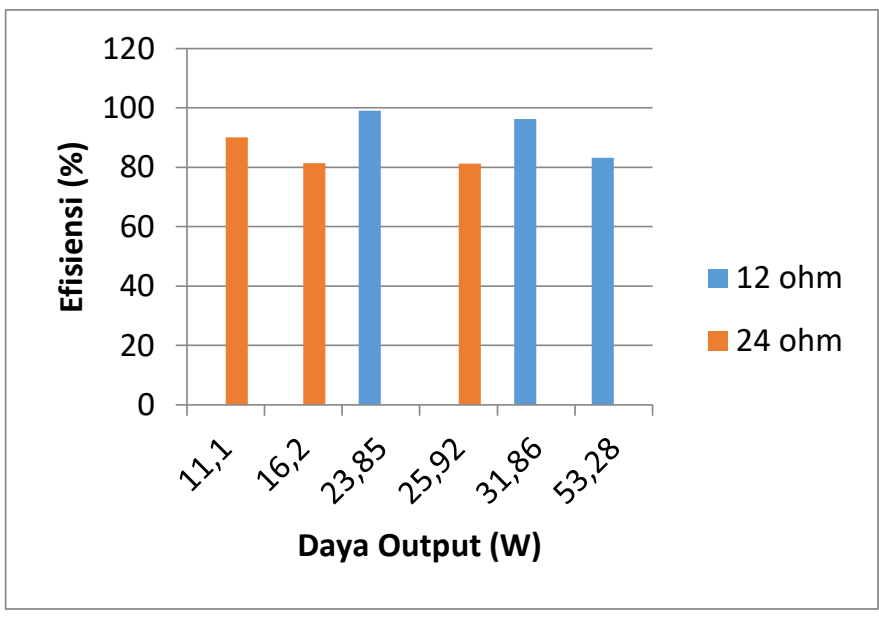

Gambar 12. Grafik Efisiensi.

Berhasilnya suatu kerja alat adalah dari perhitungan nilai efisiesi pada alat. Pada tabel dan grafik diatas dapat 
dilihat bahwa efisiensi dengan beban berubah-ubah adalah berkisar antara 80\% hingga $99 \%$. Efisiensi terbesar dari beban yang digunakan adalah pada beban $53,28 \mathrm{~W} 12 \Omega$ yaitu dengan efisiesi sebesar $90,75 \%$. Efiensi alat ini suda sesuai yang. Karna Efisiensi yang diharapkan adalah sebesar mungkin dengan rugi-rugi daya sekecil mungkin. Rugi-rugi daya terjadi disebabkan karena rangkain boost converter masih belum sesuai perancangan, dan masih terdapat beberapa kesalahan dalam perancangan yaitu kualitas komponen yang kurang bagus yang berpengaruh pada kinerja rangkaian dan pada perhitungan nilai komponen yang kurang tepat serta kesalahan dalam merangkai.

\section{PENUTUP}

Berdasarkan dari pengujian yang dilakukan diatas maka dapat disimpulkan bahwa besarnya PWM (duty cycle) pada rangkaian Boost Converter dapat diatur menggunakan potensiometer untuk memperoleh tegangan keluaran yang bervariabel antara 12VDC-24VDC. Bertambahnya duty cycle karena beban yang semakin besar dapat mempengaruhi tegangan keluaran boost converter dan berakibat pada efisiensi alat. Pembacaan sensor yang di tampilkan pada GUI (graphical user interface) Matlab terdapat sedikit perbedaan dengan nilai alat ukur. Hal ini dikarenakan resolusi pada sensorsensor yang digunakan sangat kecil,sehingga pembacaan tegangan dan arus pada sensor tidak begitu tepat.

\section{REFERENSI}

[1] F. Padillah, S. SYAHRIAL, and S. SAODAH, "Perancangan dan Realisasi Konverter DC-DC Tipe Boost Berbasis Mikrokontroler ATMEGA 8535," REKA ELKOMIKA, vol. 2, no. 1, 2014.

[2] Rashid. (2001). Power Electronics Handbook. Canada:Academic Press., No Title. .

[3] H. Matalata and L. W. Johar, "Analisa Buck Converter Dan Boost Converter Pada Perubahan Duty Cycle Pwm Dengan Membandingkan Frekuensi PWM 1, 7 Khz DAN 3, 3 Khz," J. Ilm. Univ. Batanghari Jambi, vol. 18, no. 1, pp. 42-50, 2018.

[4] M. A. Mazta, A. S. Samosir, and A. Haris, "Rancang bangun interleaved boost converter berbasis Arduino," Electrician, vol. 10, no. 1, pp. 27-35, 2016.

[5] R. O. Caceres and I. Barbi, "A boost DC-AC converter: analysis, design, and experimentation," IEEE Trans. power Electron., vol. 14, no. 1, pp. 134141, 1999.

[6] S. Badri and K. Krismadinata, "Design of Boost Converter Integrated with Graphical User Interface," Motiv. J. Mech. Electr. Ind. Eng., vol. 2, no. 1, pp. 31-42, 2020.

[7] Aswardi. 2010. Modul Elektronika Daya. Padang : Teknik Elektro Universitas Negeri Padang., "No Title."

[8] M. A. Assyidiq, B. Winardi, and T. Andromeda,
"Perancangan Boost Converter Menggunakan Voltage Feedback Pada Panel Surya," Transient J. Ilm. Tek. Elektro, Vol. 6, No. 3, Pp. 404-410, 2017.

[9] F. Hidayat And K. Krismadinata, "Rancang Bangun Vvvf Inverter 3 Fasa Untuk Operasi Motor Induksi Tiga Fasa Dengan Antarmuka Komputer," Invotek J. Inov. Vokasional Dan Teknol., Vol. 19, No. 2, Pp. 4756, 2019.

[10] I. Oktariawan, "Pembuatan Sistem Otomasi Dispenser Menggunakan Mikrokontroler Arduino Mega 2560," J. Ilm. Tek. Mesin, Vol. 1, No. 2, 2013.

[11] H. Husnawati, R. Passarella, S. Sutarno, And R. Rendyansyah, "Perancangan Dan Simulasi Energi Meter Digital Satu Phasa Menggunakan Sensor Arus Acs712," J. Nas. Tek. Elektro Dan Teknol. Inf., Vol. 2, No. 4, Pp. 307-315, 2013.

[12] M. I. Dzakwan, I. Setiawan, A. Warsito, And T. Andromeda, "Perancangan Konverter Arus Searah Tipe Penurun Tegangan Dengan Mosfet Sinkron Dan Tanpa Mosfet Sinkron," Transient J. Ilm. Tek. Elektro, Vol. 7, No. 1, Pp. 160-165, 2018.

[13] B. Hahn And D. Valentine, Essential Matlab For Engineers And Scientists. Academic Press, 2016.

\section{Biodata Penulis}

Aswaldi Alfaris, lahir di Palangka raya, 10 Desember 1998. Menyelesaikan studi DIV Teknik Elektro Industri pada Jurusan Teknik Elektro Fakultas Teknik Universitas Negeri Padang.[1]

Dr. Muldi Yuhendri, S.Pd, MT, lahir di Kampung Aur, 13 Desember 1981. Sarjana Pendidikan Teknik Elektro, Universitas Negeri Padang tahun 2005, S2 Teknik Elektro Sistem Tenaga, ITS tahun 2009, S3 Ilmu Teknik Elektro, ITS tahun 2017. Staf pengajar pada jurusan teknik elektro FT UNP sejak tahun 2006 sampai sekarang.[2] 